\title{
Comparative Study of PCR and ELIZA for the Detection of Foot and Mouth Disease in Cattle
}

\author{
Abdul Sajid ${ }^{* 1}$, Natasha Kashif ${ }^{2}$, Muhammad Bilal ${ }^{3}$, Mian Muhammad Salman ${ }^{1}$, Saeed Ahmad ${ }^{4}$ and Jun $\mathrm{Li}^{4}$ \\ ${ }^{1}$ College of Veterinary Sciences and Animal Husbandry, Abdul Wali Khan University Mardan, Pakistan \\ ${ }^{2}$ Department of Microbiology, Abasyn University Peshawar, Pakistan \\ ${ }^{3}$ Foot and Mouth Disease research Center, Veterinary Research Institute Peshawar, Pakistan \\ ${ }^{4}$ National Reference Laboratory of Veterinary Drug Residues (HZAU), China \\ *Corresponding author: Abdul Sajid, College of Veterinary Sciences and Animal Husbandry, Abdul Wali Khan University, Mardan, Pakistan, E-mail: \\ sajidvet137@awkum.edu.pk
}

Received date: December 22, 2017; Accepted date: January 09, 2018; Published date: January 16, 2018

Copyright: $\odot 2018$ Sajid A, et al. This is an open-access article distributed under the terms of the Creative Commons Attribution License, which permits unrestricted use, distribution, and reproduction in any medium, provided the original author and source are credited.

\begin{abstract}
Among viral diseases of animals, Foot and Mouth Disease is an exceedingly transferable disease of clovenhoofed animals caused by the virus of class Aphthovirus, family Picornaviridae. In the present study the Indirect Sandwich ELISA negative samples were tested through PCR and a range of OD for false negative ELISA samples was adjusted in order to decide whether the samples are actually positive or negative. Total 50 ELISA's negative samples were confirmed through PCR. Out of total 50 ELISA's negative samples, 23 were positive for PCR while rests of the 27 samples were found negative. In the PCR positive samples 13, 2 and 3 were positive for Serotype "O", "A" and "Asia-1", respectively. While 2 samples were positive for O and A and 3 for O and Asia-1 mixed infection. On the basis of type of samples, it was found that 18 out of 25 epithelial tissue samples and 5 out of 25 swab samples were positive. It was concluded that the ELISA negative samples with OD value 0.05 to 0.09 will be considered positive while the samples with OD value 0.04 or below should be considered negative. The epithelial tissues either from the oral commissar of foot region is the representative sample for diagnostic purpose.
\end{abstract}

Keywords Foot and mouth disease; PCR; ELISA; PCR and ELISA comparison; Cutoff value

\section{Introduction}

Livestock sector play an important role in economy of Pakistan. Animal diseases are important factor in lowering productivity of animals. Foot and Mouth Disease cause significant economic losses [1]. Foot and Mouth Disease are endemic in Pakistan [2,3]. Experiences have revealed that public health, food supply and national economy are directly related with the infectious diseases of farm animals (WHO).

Among viral diseases, Foot and Mouth Disease is a highly communicable disease of cloven-hoofed animals [4-6] caused by a virus of the genus Aphthovirus, family Picornaviridae [7]. It genome contain a single stranded positive-sense RNA molecule of approximately $8 \mathrm{~kb}$ [8]. There are seven serotypes of Foot and Mouth Disease virus O, A, C, Asia 1, SAT 1, SAT 2, and SAT 3 [9]. Among the domesticated species, cattle, buffalo, sheep, goat and pig are most susceptible to Foot and Mouth Disease [10]. It is documented that there is no cross immunity among these serotypes due to difference in their antigenicity [11].

Clinically Disease is characterized by anorexia, fever, and vesicles on the mucous membrane of the mouth [12]. On the feet, lesions are most prominent between the digits and bulbs of the heel (Mann\&Seller). In female, the mammary gland is affected. The virus takes shelter and survives in the cells of the pharyngeal epithelium. The timely investigations would increase disease awareness and epidemiological information [13].
Timely reporting of the outbreak and diagnosis of the persistent and carrier cases led to the effective control of the disease in the sense that its transmission is minimized. These can be achieved when animals are vaccinated with field strains regularly and when rapid, sensitive and specific diagnostic techniques are available. Many efforts have been made to develop new techniques for the diagnosis of this disease. For the diagnosis of clinical cases conventional techniques are still in use. For the detection of specific antigen in the epithelial tissues Sandwich ELISA is being used accompanied by concurrent cell culture isolation [14].

With the passage of time new molecular techniques which based on viral genome detection including RT-PCR are now used for the specific FMDV RNA [15]. After evaluation it was reported that RT-PCR has the same sensitivity and specificity like ELISA and virus isolation [14].

Currently, the Foot and Mouth Disease in our country (Pakistan) is being diagnosed through ELISA technique developed at Project "Progressive Control of Foot and Mouth Disease in Pakistan" funded by the US government through FAO by NVL Islamabad Pakistan which includes Virus isolation (VI), Sandwich-ELISA (S-ELISA), Liquid- Phase Blocking ELISA (LPBE) and 3ABC ELISA which is an indirect ELISA for detection of antibody against nonstructural proteins. Generally S-ELISA is being used for the antigen detection but because of its low sensitivity currently PCR is being used. The RTPCR-based detection method is used in many reference laboratories in the world for the purpose.

In the present study the sensitivity of the Indirect Sandwich ELISA used for the detection of Foot and Mouth Disease Virus was focused in the sense that ELISA negative samples should be tested through PCR 
Page 2 of 4

and a range of OD for false negative ELISA samples must be adjusted in order to decide whether the sample is actually positive or negative.

\section{Materials and Methods}

In the present study a total of 50 ELISA negative samples were tested through PCR for confirmation that either the

Samples are actual or false negative. During the study the results of PCR positive samples were compared with the OD values obtained through ELISA and a cutoff value was adjusted that in future the ELISA negative samples with that much OD value must be retested with PCR for confirmation. STUDY AREA: The samples from throughout Khyber Pakhtunkhwa were tested through ELISA for the diagnosis of Foot and Mouth Disease at Veterinary Research Institute, Peshawar. The ELISA negative samples were randomly selected and tested through PCR.ELISA

\section{Method}

A volume of $50 \mu \mathrm{l}$ of 1:1000 diluted trapping Antibody were added to all wells in the following order: Serotype

\section{Row A and E: Serotype O}

Row B and F: Serotype A

Row $\mathrm{C}$ and G: Serotype $\mathrm{C}$

Row D and H: Serotype Asia-I

Then the plates were incubated at $37^{\circ} \mathrm{C}$ for one hour. At the completion of incubation period the plates were washed three times with wash buffer. After it $50 \mu \mathrm{l}$ of diluent buffer A to wells of column 1-6 (plate 1 only) and $12.5 \mu \mathrm{l}$ of control Ag "O" to well 1 of row A and E, $12.5 \mu \mathrm{l}$ of control Ag "A" to well 1 of row B and F, $12.5 \mu \mathrm{l}$ of control $\mathrm{Ag}$ "C" to well 1 of row C and G, $12.5 \mu \mathrm{l}$ of control Ag "Asia I" to well 1 of row D and H, $50 \mu \mathrm{l}$ sample 1 to wells A7/8 to D7/8 and $7.50 \mu \mathrm{l}$ of sample 2 to wells E7/8 to H7/8 were added. Then again, the plates were incubated at $37^{\circ} \mathrm{C}$ for one hour. After the completion of incubation the plates were washed three times. In the next step $50 \mu \mathrm{l}$ of detecting $\mathrm{O}, \mathrm{A}$, $\mathrm{C}$ and Asia 1 Antibodies were added to rows in following order. Serotype "O" Antibodies: Row A and E Serotype "A" Antibodies: Row B and F Serotype "C" Antibodies: Row C and G Serotype "Asia 1" Antibodies: Row $\mathrm{D}$ and $\mathrm{H}$, Then the plates were incubated in a shaking incubator at $37^{\circ} \mathrm{C}$ for $\mathrm{I} \mathrm{h}$ and were washed three times after the completion of incubation period. Then $50 \mu$ l conjugate were added to all wells and incubated for $45 \mathrm{~min}$. The washing step was repeated.
Finally $50 \mu \mathrm{l}$ Substrate/chromogen were added to all (96) wells and were incubated at room temperature for $15 \mathrm{~min}$ in dark. It the end 50 $\mu$ Stopping solution (1.25 $\mathrm{M} \mathrm{H}_{2} \mathrm{SO}_{4}$ ) was added to all (96) wells and plates were shacked briefly and read at $492 \mathrm{~nm}$ filter.

\section{Procedure for PCR}

RNA Extraction: The RNA was extracted through the kit (Viral Nucleic Acid Extraction Kit II, Real Genomics by Real Biotech Corporation) method.

PCR procedure: The PCR protocol was followed as described by the manufacturer. The kit used in the present study is manufactured by shanghai ZJ Bio-Tech Co. Ltd. A $20 \mu$ master mix with a micropipette of sterile filter tips were added to each PCR tube $5 \mu$ l RNA sample template and molecular grade water to different tubes. The tubes were closed immediately to avoid contamination. The tubes with master mix were centrifuged in order to collect it at the bottom. The following protocol was followed. $45^{\circ} \mathrm{C}$ for $20 \mathrm{~min}, 1$ cycle $94^{\circ} \mathrm{C}$ for $2 \mathrm{~min}, 1 \mathrm{cycle}$ $93^{\circ} \mathrm{C}$ for $15 \mathrm{~s}, 72^{\circ} \mathrm{C}, 30 \mathrm{~s}, 35$ cycles.

\section{Agarose gel electrophoresis:} dye

The DNA samples were mixed with $0.20 \mu$ of the desired gel loading

The lid of the gel tank were closed and attached to the electrical leads so that the DNA migrates towards the positive anodes. When the dye indicating the DNA migrates to a sufficient distance through the gel the electric current were switched off and the lid of the gel tank were opened by removing the leads. At the end the gel were examined under

UV light and images were saved.

\section{Results}

In the present study a total of 50 ELISA negative samples received from throughout the Khyber Pakhtunkhwa for the diagnosis of Foot and Mouth Disease were tested through PCR for confirmation that either the samples were actually negative or false negative at Veterinary Research Institute, Peshawar, Khyber Pakhtunkhwa.

Out of total 50 ELISA negative samples 23 were positive through PCR. In PCR positive samples 13, 2 and 3 were positive for Serotype "O", "A" and "Asia-1", respectively. While 2 samples were positive for $\mathrm{O}$ and $\mathrm{A}$ and 3 for $\mathrm{O}$ and Asia-1 mixed infection (Table 1).

\begin{tabular}{|c|c|c|c|c|c|c|c|}
\hline \multirow[t]{2}{*}{ Total sample } & \multirow[t]{2}{*}{ Negative sample } & \multirow[t]{2}{*}{ PCR positive sample } & \multicolumn{5}{|c|}{ Mixed infection } \\
\hline & & & O +ive & A +ive & A1 +ive & $O$ and $A+i v e$ & $\mathrm{O}$ and $\mathrm{A} 1$ +ive \\
\hline 50 & 27 & 23 & 13 & 2 & 3 & 2 & 3 \\
\hline
\end{tabular}

Table 1: Detail of the total samples tested through ELISA and PCR

On the basis of type of samples the analysis of data shows that two types of samples were used in the present study. It was found that 18 out of 25 epithelial tissue samples and 5 out of swab samples were positive (Table 2).

\begin{tabular}{|l|l|l|c|}
\hline Type of Sample & Total samples & $\begin{array}{c}\text { Positive } \\
\text { sample }\end{array}$ & $\begin{array}{c}\text { Negative } \\
\text { sample }\end{array}$ \\
\hline
\end{tabular}

\begin{tabular}{|c|c|c|c|}
\hline Epithelial tissue & 25 & 18 & 7 \\
\hline Swab sample & 25 & 5 & 20 \\
\hline Total & 50 & 23 & 27 \\
\hline
\end{tabular}

Table 2: Sample type wise analysis of the data 
Citation: Sajid A, Kashif N, Bilal M, Salman MM, Ahmad S, et al. (2018) Comparative Study of PCR and ELIZA for the Detection of Foot and Mouth Disease in Cattle. J Vaccines Vaccin 9: 382. doi:10.4172/2157-7560.1000382

Page 3 of 4

After the completion of the trial it was observed that the ELISA negative samples with OD value 0.05 to 0.09 were found positive for PCR while the samples with OD value below 0.05 were negative for PCR (Table 3) (Figure 1 and Figure 2).

\begin{tabular}{|c|c|c|c|}
\hline \multirow{2}{*}{$\begin{array}{c}\text { ELISA Result/OD } \\
\text { Value }\end{array}$} & \multicolumn{3}{|c|}{ PCR Result } \\
\cline { 2 - 4 } & FMDV-O & FMDV-A & FMDV-A-1 \\
\hline
\end{tabular}

\begin{tabular}{|c|c|c|c|}
\hline $0.05-0.09$ & $P$ & $P$ & $P$ \\
\hline$\leq 0.04$ & $\mathrm{~N}$ & $\mathrm{~N}$ & $\mathrm{~N}$ \\
\hline
\end{tabular}

Table 3: Range of samples OD values and PCR response

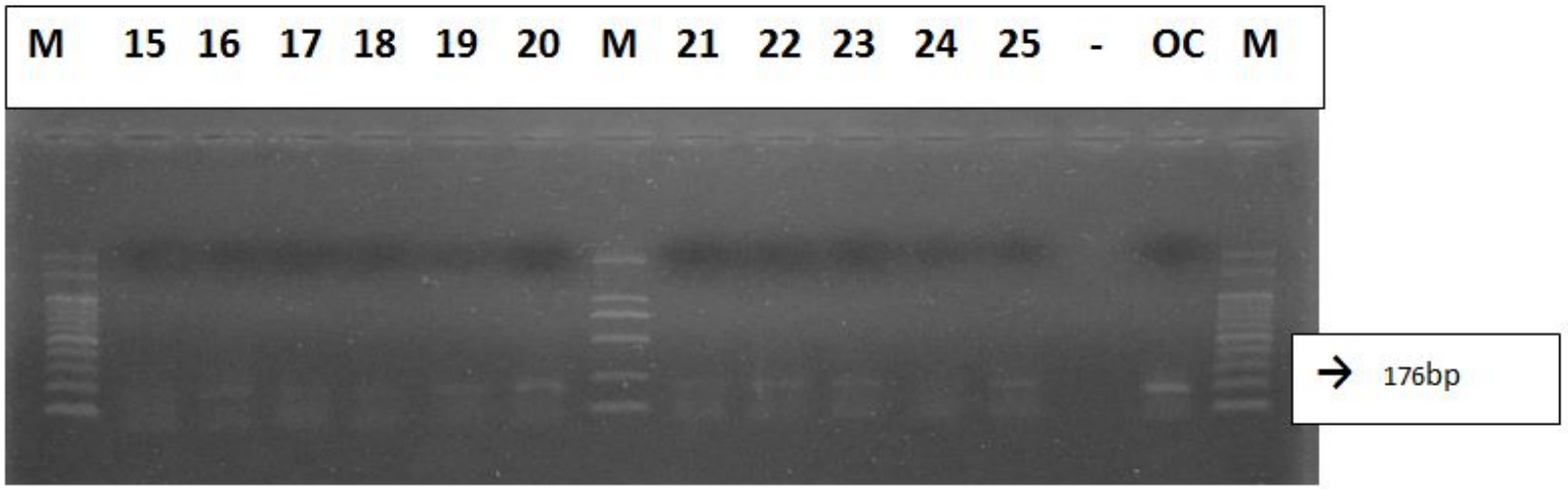

Figure 1: PCR performed on samples from 15 to 25 for FMD viral strain O Samples 16, 17, 19, 20, 21, 22, 23 and 25 are positive for O strain. Whereas 15,18 and 24 are negative.

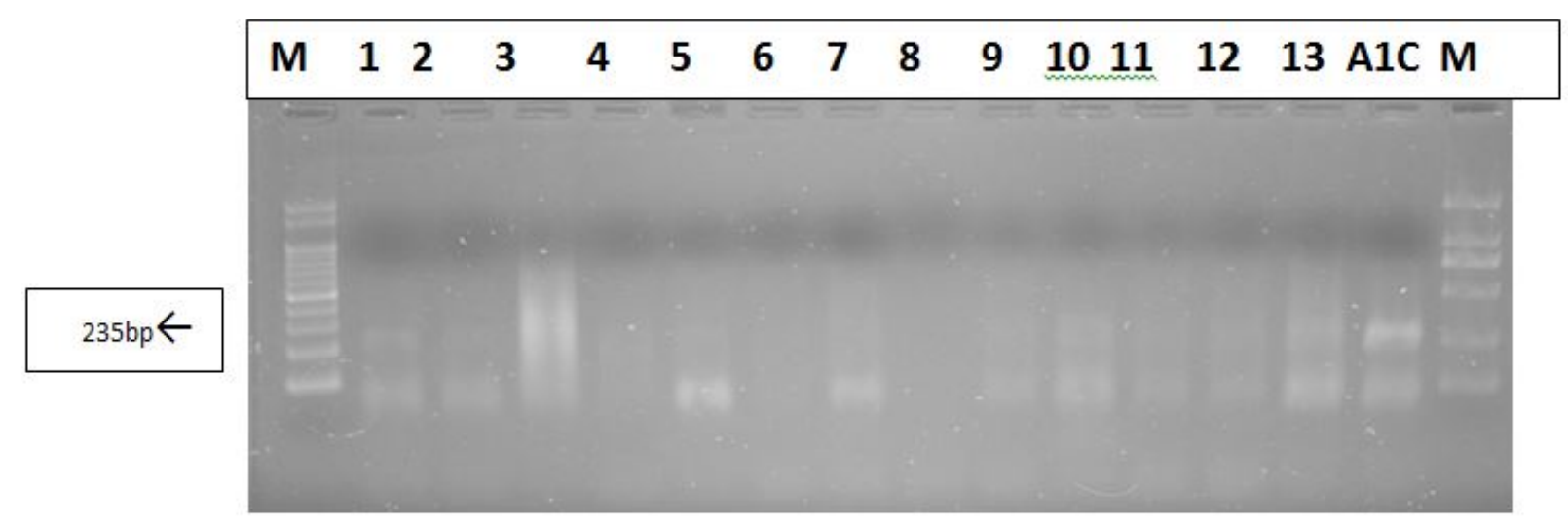

Figure 2: PCR performed on samples from 15 to 25 for FMD viral strain Asia-1. Sample No.1 is positive for Asia-1 strain whereas the rest of the samples are negative.

\section{Discussion}

The highly contagious nature, accompanied with the remarkable economic losses, make FMDV of a primary animal health concern worldwide. Effective vaccines and strict control measures have enabled FMD eradication in most developed countries, which maintain unvaccinated, seronegative herds in compliance with strict international trade policies. However, the disease remains enzootic in many regions of the world, posing a serious problem for commercial trade with FMD-free countries.

It has been established that rapid control of FMD is foremost to reduce dissemination of the causative virus to other non-infected regions. Also, characterization of the FMDV serotype is essential for tracing source of the virus with proper selection of effective vaccine. Accordingly, this work was conducted for the selection of sensitive technique and type of representative sample for rapid diagnosis, to control severe losses of outbreak among livestock. Diagnosis of FMD depends basically on clinical findings, isolation of the causative agent and specific antigen detection. Infected animals from which the Specimens were collected, exhibited typical and severe signs of FMD. The collected specimens (tongue and foot epithelia and swab samples) were used for PCR and Indirect Sandwich ELISA.

In the present study it was observed that field specimens do not contain enough viral antigens to be directly detected by an ELISA. Similar findings were also reported. Therefore, PCR was the test of choice for rapid detection and serotype identification of the outbreak 
Citation: Sajid A, Kashif N, Bilal M, Salman MM, Ahmad S, et al. (2018) Comparative Study of PCR and ELIZA for the Detection of Foot and Mouth Disease in Cattle. J Vaccines Vaccin 9: 382. doi:10.4172/2157-7560.1000382

Page 4 of 4

causative agent. RT-PCR results confirmed that there was a FMDV infection by amplifying the FMDV VP1-derived 176 bp and $235 \mathrm{bp}$ fragment and excluded possibilities for presence of other vesicular diseases.

\section{Novelty}

During the study the results of PCR positive samples (already reported negative via ELISA by having OD value less than 01 , a recommended cutoff value of the kit) were compared with the OD values obtained through ELISA and a cut off value was adjusted for the purpose that in future the ELISA negative samples with that much OD value ( 0.05 to 0.09 ) must be retested with PCR for confirmation, while the samples with OD value below 0.05 will always be considered negative for PCR. The hypothesis that the ELISA negative samples with OD value near to the cutoff might be positive was true.

In order to avoid the false negative results and control this endemic and economically important disease timely it is recommended that the ELISA negative samples with above mentioned OD values must be retested through PCR for confirmation. In this way all efforts, expenses and time used will not be wasted but will be fruitful. This will further help in the mass or ring vaccination of the selected area.

\section{References}

1. Ajmal M, Arshad M, Ahmad MD (1989) Coordinated Research entitled Epidemiology of Major Livestock Diseases in Pakistan (Pilot Study). 5th Annual Report. Pakistan Agri Res 5: 3

2. Anjum R, Hussain M, Zahoor Irshad H, Farooq U (2006) Epidemiological analyses of Foot and Mouth disease in Pakistan. Int J Agric Biol 5: 648-651.

3. OIE (World Organisation for Animal Health) (2007) SEAFMD (SouthEast Asia Foot and Mouth Disease Campaign) SEAFMD 2020: A
Roadmap for foot and mouth disease freedom with vaccination by 2020 in South-East Asia.

4. Farahnaz MS, Hoorieh S, Amir RJ, Homayoon M (2012) Comparison of Immune Responses against FMD by a DNA Vaccine Encoding the FMDV/O/IRN/2007 VP1 Gene and the Conventional Inactivated Vaccine in an Animal Model. J Virol Sin 27: 286-291.

5. Yao-zhong D, Yong-sheng L, Jian-hua Z, Hao-tai C, Gang W, et al. (2011) A highly sensitive detection for foot-and-mouth disease virus by gold nanoparticle improved immuno-PCR. Virology 8: 34-39.

6. Bartley LM, Donnelly CA, Anderson RM (2002) Review of foot-andmouth disease virus survival in animal excretions and on fomites. Vet Rec 151: 667- 669 .

7. Pereira HG (1981) Foot-and-mouth disease virus. Virus Diseases of Food Animals 2: 333-363.

8. Sangar DV, Rowlands DJ, Harris TJ, Brown F (1977) Protein covalently linked to foot-and-mouth disease virus RNA. Nature 18: 648-650.

9. Afzal H, Ellahi A (1966) A study of foot and mouth disease in Pakistan. Bull Int Epizoot 65: 101-110.

10. FAO World Reference Laboratory for Foot-and-Mouth Disease (1998) Cumulative Report.

11. Kitching RP, Knowles NJ, Samuel AR, Donaldson AI (1989) Development of Foot and Mouth disease virus strain characterization. Trop Anim Hlth Prod 21: 153-166.

12. Thomson GR, Coetzer JAW, Tustin RC (1994) Infectious Diseases of Livestock with Special Reference to Southern Africa, Oxford University Press Southern Africa 2: 825-851.

13. Zhang ZD, Kitching RP (2001) The localization of persistent Foot and Mouth Disease virus in the epithelial cells of the soft palate and pharynx. J Comp Pathol 124: 89-94.

14. Paul S, Barteling SS, Raul CO, Keith JS (2003): Control and eradication of foot-and-mouth disease. Virus Res 91: 101-144.

15. Alexandersen S, Zhang Z, Donaldson AI, Garland AJM (2003) The pathogenesis and diagnosis of Foot-and-Mouth Disease. J Comp Pathol 129: 1-36. 